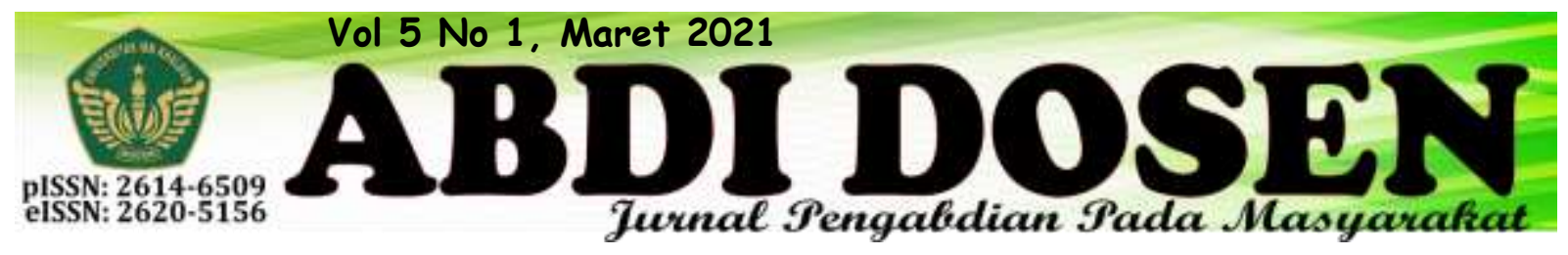

\title{
PELATIHAN PEMERIKSAAN PAYUDARA SENDIRI (SADARI) PADA SISWI SMA BINA LESTARI KECAMATAN GANDUS SEBAGAI UPAYA PENCEGAHAN KANKER PAYUDARA
}

\author{
Ismar Agustin $^{1}$, Intan Kumalasari ${ }^{2}$, Herawati Jaya ${ }^{3}$ \\ baropagustin@gmail.com $^{1}$ \\ zoominar123@gmail.com ${ }^{2}$ \\ heraj39@yahoo.com ${ }^{3}$ \\ Prodi D IV Keperawatan ${ }^{1}$, Prodi D III Keperawatan Lubuk Linggau² ${ }^{2}$ Prodi D III Keperawatan Palembang ${ }^{3}$
}

\begin{abstract}
Breast cancer has become one of the most common female malignant tumors in the world and a leading cause of death. Disease is prevalent in low-and middle-income countries where most cases are diagnosed at an advanced stage. Still finding cases at an early stage makes early detection and screening efforts very important. The prognosis for long-term cure is relatively high if cancer is detected early and managed regularly. Health education is a practical and effective method to raise awareness of women about the importance of early detection of breast cancer. Health education has been proven to be effective in increasing knowledge and frequency of breast examinations with BSE. This activity aims to provide training through increasing the knowledge and skills of young women, especially Bina Lestari Palembang high school students in early detection of breast cancer with BSE. The training method is counseling by providing education and breast self-examination with BSE. Pre test and post test before and after training. The results of the counseling had a positive impact on the training participants where most of the students experienced a significant increase in knowledge after attending breast self-examination training as an effort to prevent breast cancer.
\end{abstract}

Keywords : Breast Self-Examination (BSE), Breast Cancer, Health Education, Teenagers

\begin{abstract}
ABSTRAK
Kanker payudara telah menjadi salah satu tumor ganas wanita paling umum di dunia dan penyebab utama kematian. Penyakit ini lazim di negara-negara berpenghasilan rendah dan menengah di mana kebanyakan kasus di diagnosis pada stadium lanjut. Masih ditemukannya kasus pada tahap awal membuat upaya deteksi dan skrining dini menjadi sangat penting. Prognosis penyembuhan jangka panjang relatif tinggi jika kanker dideteksi sejak dini dan ditangani secara teratur. Pendidikan kesehatan merupakan metode yang praktis dan efektif untuk meningkatkan kesadaran perempuan tentang pentingnya deteksi dini kanker payudara. Pendidikan kesehatan terbukti efektif meningkatkan pengetahuan dan frekuensi pemeriksaan payudara dengan SADARI. Kegiatan ini bertujuan untuk memberikan pelatihan melalui peningkatan pengetahuan dan keterampilan remaja putri khususnya siswa SMA Bina Lestari Palembang dalam deteksi dini kanker payudara dengan SADARI. Metode pelatihannya
\end{abstract}


adalah konseling dengan memberikan edukasi dan pemeriksaan payudara sendiri dengan SADARI. Pre test dan post test sebelum dan sesudah pelatihan. Hasil penyuluhan berdampak positif bagi peserta pelatihan dimana sebagian besar siswi mengalami peningkatan pengetahuan yang signifikan setelah mengikuti pelatihan SADARI sebagai upaya pencegahan kanker payudara.

\section{Kata Kunci : Pelatihan SADARI, Kanker Payudara, Pendidikan Kesehatan, remaja}

\section{PENDAHULUAN}

Kanker payudara sampai sekarang masih menjadi masalah kesehatan masyarakat yang utama di seluruh dunia dan merupakan penyebab morbiditas dan mortalitas yang signifikan karena merupakan penyebab kematian nomor dua pada wanita (American Cancer Society, 2009). Penyakit ini lazim terjadi di negara berpenghasilan rendah dan menengah di mana sebagian besar kasus terdiagnosis pada stadium lanjut. WHO mencatat 18,1 juta kasus baru dan 9,6 juta kematian di seluruh dunia akibat kanker payudara (Globocan, 2018). Sementara di Indonesia kanker payudara menyumbang $30,9 \%$ dari semua diagnosa kanker dengan prevalensi sebesar 42,1 per 100.000 penduduk, $58.256(16,7 \%)$ kasus baru dengan angka kematian sebesar 17 per 100.000 penduduk (Globocan, 2018).

Meskipun kanker payudara telah menjadi salah satu tumor ganas wanita paling umum di dunia dan menjadi penyebab utama kematian (Winters, S., et.al. 2017, Shah, TA., et.al. 2017, Takkar, N., et.al. 2017), namun jika terdeteksi sejak dini dan dirawat secara teratur, angka kesembuhan jangka panjang relatif tinggi (Shankar, A., et.al. 2017, Evans, RL., et.al. 2018 dan Esmail, HE., et.al. 2017). Saat ini, tidak ada tindakan pencegahan yang efektif untuk kanker payudara, hanya melalui diagnosis dini dan pengobatan lesi yang tepat waktu dapat menurunkan angka kematian dan kualitas hidup pasien dapat ditingkatkan (Wachira, J., et.al. 2017, dan Reichart, K., et.al 2017). Studi menunjukkan bahwa skrining kanker payudara dapat menurunkan angka kematian akibat kanker payudara sebesar $7 \%$ pada wanita usia 40-49 dan $11 \%$ pada wanita usia 50-69. Survei yang dilakukan oleh Olasehinde, O., et.al. (2017), menunjukkan bahwa mendeteksi, mendiagnosis dan mengobati kanker payudara secara dini adalah kunci untuk mengurangi kematian akibat kanker payudara. Masih sedikitnya penemuan kasus dalam stadium dini menyebabkan upaya deteksi dini dan skrening menjadi sangat penting.

Rendahnya kesadaran untuk memeriksakan diri tidak hanya terjadi pada wanita dengan pendidikan dan ekonomi rendah, tetapi juga terjadi pada wanita yang berpendidikan tinggi dan cukup mapan. tingginya angka kematian perempuan akibat kanker payudara akan terus meningkat jika pengetahuan dan kesadaran wanita akan pentingnya deteksi dini masih rendah. American Cancer Association merekomendasikan tiga metode skrining awal yang efektif untuk mendeteksi kanker payudara yaitu pemeriksaan payudara sendiri (SADARI), pemeriksaan payudara klinis (SADANIS), dan mamografi untuk mendeteksi kanker payudara pada wanita tanpa gejala (Jacobsen, KK., et.al. 2017., Bahl, M., et.al., 2017 dan Dogan, BE., et.al. 2017). 
Meskipun SADARI dianggap sebagai perilaku yang sehat untuk deteksi dini kanker payudara, namun penerapan SADARI dan SADANIS di Indonesia belum berjalan secara optimal. Riset Penyakit Tidak Menular (PTM) 2016 menyatakan perilaku masyarakat dalam deteksi dini kanker payudara masih rendah dimana 53,7\% masyarakat tidak pernah melakukan SADARI, dan 95,6\% masyarakat tidak pernah melakukan SADANIS. Studi menunjukkan bahwa pendidikan kesehatan dapat meningkatkan pengetahuan, keyakinan, dan sikap wanita terhadap SADARI. Pendidikan kesehatan adalah metode yang praktis dan efektif untuk meningkatkan kesadaran wanita tentang pentingnya deteksi dini kanker payudara. Pendidikan kesehatan telah terbukti efektif meningkatkan pengetahuan dan frekuensi pemeriksaan payudara dengan teknik SADARI (Akhtari, ZM., et.al, 2016, Vithana, PC., et.al, 2015, Heydari, E., et.al, 2015 dan Wang, JH., et.al, 2012)

SMA Bina Lestari Palembang merupakan salah SMA yang berada diwilayah kerja Puskesmas Gandus dan menjadi salah satu SMA yang dijadikan lokasi Kegiatan Pengabdian Masyarakat yang terintegrasi dengan mata kuliah

\section{METODE PELAKSANAAN}

Kegiatan pengabdian masyarakat ini dilaksanakan dengan menggunakan metode pelatihan yaitu penyuluhan dengan pemberian edukasi dan demonstrasi melalui beberapa tahapan mulai dari persiapan, pelaksanaan sampai evaluasi kegiatan, antara lain sebagai berikut:

1. Tahap Persiapan :

a. Melakukan identifikasi sekolah yang memenuhi kriteria sebagai mitra, diantaranya lokasi di
Keperawatan Maternitas. Berdasarkan data awal yang dikumpulkan oleh tim pengabmas, Puskesmas sebagai perpanjangan tangan Program Dinas Kesehatan Kota, belum melaksanakan secara maksimal kegiatan Pelayananan Kesehatan Peduli Remaja (PKPR), sehingga remaja putri khususnya siswi SMA Bina Lestari Palembang belum pernah mendapatkan informasi tentang deteksi dini kanker payudara dengan SADARI. Tujuan kegiatan Pengabmas ini adalah memberikan pelatihan melalui peningkatan pengetahuan dan keterampilan remaja putri, khususnya siswi SMA Bina Lestari Palembang dalam melakukan deteksi dini kanker payudara dengan tehnik SADARI sehingga dapat meningkatkan kesadaran remaja dalam deteksi dini kanker payudara dan meningkatkan partisipasi aktif remaja dalam upaya sosialisasi deteksi dini kanker payudara.

Berdasarkan penjelasan diatas dan didukung oleh berbagai data dan sumber, maka peneliti tertarik untuk melakukan pengabmas mengenai "IbM Pelatihan Pemeriksaan Payudara Sendiri (SADARI) pada Siswi SMA Bina Lestari Kecamatan Gandus Sebagai Upaya Pencegahan Kanker Payudara.

pinggiran kota, jarak tempuh $9 \mathrm{~km}$ dari pusat kota, belum pernah dilaksanakan pendidikan kesehatan maupun sosialisasi oleh stakeholder/petugas kesehatan terkait materi tentang deteksi dini kanker payudara dengan SADARI, belum tersedianya fasilitas sekolah yang menunjang pengetahuan siswi terkait kesehatan reproduksi remaja seperti pelayanan kesehatan peduli 
remaja dan belum tersedianya tenaga guru atau siswi yang menjadi duta kesehatan reproduksidi sekolah.

b. Mempersiapkan tempat dan sarana pelaksanaan pendidikan kesehatan, misalnya ruang tempat penyuluhan, sarana belajar menggunakan kursi, tikar, karpet, infokus, VCD player, leaflet, buku, poster dan alat peraga seperti panthom payudara.

c. Mempersiapkan materi, alat bantu penyuluhan dan jadwal pelaksanaan serta mempelajari materi yang akan disampaikan.

d. Persiapan peserta yakni dengan mengundang siswi remaja putri kelas X, XI, XII untuk mengikuti kegiatan pelatihan deteksidini kanker payudara dengan SADARI

e. Membuat rencana pelaksanan kegiatan dengan pihak sekolah

f. Menentukan waktu pertemuan yang disesuaikan dengan jadwal pelajaran kosong siswa atau waktu yang telah disepakati, bisa dilakukan pada jam istirahat atau selepas ishoma dengan lama waktu pertemuan 120 menit

g. Pertemuan dilakukan sebanyak dua kali sesuai dengan hasil kesepakatan dengan peserta.

h. Setiap peserta akan diberikan formulir kesediaan untuk ikut dalam kegiatan pelatihan, siswi yang bersedia kemudian diberikan pre tes untuk mengukur tingkat pengetahuan dan pemahaman siswi SMA Bina Lestari sebelum diberikan pelatihan.

2. Tahap Pelaksanaan :

a. Pemberian materi edukasi disampaikan oleh fasilitator yaitu dosen Jurusan Keperawatan
Poltekkes Palembang. Adapun materi yang disampaikan diantaranya 1. Pengertian Kanker Payudara 2. Gejala dan tanda kanker Payudara 3. Mitos seputar kanker payudara dan 4. Deteksi dini kanker payudara dengan metode SADARI (pemeriksaan payudara sendiri). Pada tahap ini siswi dibagikan leaflet, buku pintar SADARI, poster SADARI dan penayangan video tentang pemeriksaan payudara sendiri dengan teknik SADARI. Setelah fasilitator menyampaikan materi terkait deteksi dini kanker payudara dengan SADARI, kemudian dilanjutkan dengan tahap demonstrasi.

b. Tahap demonstrasi yaitu praktik pemeriksaan payudara sendiri. Kegiatan ini dipandu oleh fasilitator dan 3 orang mahasiswa yang dilibatkan secara aktif dan sebelumnya telah diberi pembekalan serta keterampilan yang memadai untuk kemudian diaplikasikan langsung kepada siswi SMA Bina Lestari Palembang. Adapun urutan dari pemeriksaan payudara sendiri (SADARI) ini adalah sebagai berikut : Berdiri tegak. Cermati bila ada perubahan pada bentuk dan permukaan kulit payudara, pembengkakan dan/atau perubahan pada puting. Bentuk payudara kanan dan kiri tidak simetris, angkat kedua lengan ke atas, tekuk siku dan posisikan tangan di belakang kepala. dorong siku ke depan dan cermati payudara; dan dorong siku ke belakang dan cermati bentuk maupun ukuran 
payudara. posisikan kedua tangan pada pinggang, condongkan bahu ke depan sehingga payudara menggantung, dan dorong kedua siku ke depan, lalu kencangkan (kontraksikan) otot dada anda, angkat lengan kiri ke atas, dan tekuk siku sehingga tangan kiri memegang bagian atas punggung. Dengan menggunakan ujung jari tangan kanan, raba dan tekan area payudara, serta cermati seluruh bagian payudara kiri hingga ke area ketiak. Lakukan gerakan atasbawah, gerakan lingkaran dan gerakan lurus dari arah tepi payudara ke puting, dan sebaliknya. Ulangi gerakan yang sama pada payudara kanan Anda, cubit kedua puting. Cermati bila ada cairan yang keluar dari puting, pada posisi tiduran ; letakkan bantal di bawah pundak kanan. Angkat lengan ke atas. Cermati payudara kanan dan lakukan tiga pola gerakan seperti sebelumnya. Dengan menggunakan ujung jari-jari, tekan-tekan seluruh bagian payudara hingga ke sekitar ketiak. Fasilitator dan mahasiswa memandu gerakan satu persatu mulai dari gerakan yang pertama sampai gerakan yang terakhir dengan diikuti oleh siswi SMA
Bina Lestari. Pemeriksaan payudara ini dianjurkan pada setiap waktu terutama pada saat mandi. Siswi yang hadir juga mendapatkan lieflet dan panduan pemeriksaan SADARI agar bisa dilakukan dirumah sendiri.

3. Tahap MOU dan Evaluasi :

Pada tahap ini dilakukan penandatanganan kesepakatan sebagai komitmen pihak sekolah dan siswi yang telah mendapatkan pelatihan untuk secara aktif mengajarkan kepada teman sebayanya. Evaluasi dalam bentuk post tes berupa kuesioner untuk menilai apakah kegiatan ini memiliki manfaat terhadap peningkatan pemahaman, perubahan perilaku dan sikap siswi SMA Bina Lestari Kecamatan Gandus Palembang. Hasil evaluasi dilaporkan kepada pimpinan Institusi Poltekkes Palembang dan pihak-pihak yang berkepentingan pada akhir pelaksanaan kegiatan pengabdian kepada masyarakat. Evaluasi kegiatan program disampaikan untuk memberikan gambaran hasil pelaksanaan kegiatan pengabdian kepada masyarakat dan juga untuk mendapatkan masukan dari berbagai pihak tentang pelaksanaan kegiatan dan perbaikan kegiatan pada masa mendatang. 


\section{HASIL dan PEMBAHASAN}

Kegiatan pengebdian kepada masyarakat ini telah dilaksanakan selama 2 hari pada bulan Oktober 2019. Kegiatan tersebut melibatkan 51 siswi SMA Bina
Lestari Kecamatan Gandus Palembang. Adapun karakteristik peserta pelatihan disajikan dalam tabel 1.

Tabel 1. Karakteristik Peserta Pelatihan Pemeriksaan Payudara Sendiri (SADARI)

\begin{tabular}{lcc}
\hline \multirow{2}{*}{ Variabel } & \multicolumn{2}{c}{ Jumlah $(\mathrm{n}=51)$} \\
\cline { 2 - 3 } & $\mathrm{n}=51$ & $\%$ \\
\hline Informasi tentang SADARI & 41 & 80,39 \\
$\quad$ Tidak pernah & 10 & 19,61 \\
$\quad$ Pernah & & \\
Usia Siswi & 0 & 0 \\
$\quad$ Remaja awal (10-12 th) & 11 & 21,56 \\
$\quad$ Remaja pertengahan (13-15 th) & 40 & 78,41 \\
$\quad$ Remaja Akhir (16-19 th) & & \\
Tingkat/Kelas & 22 & 43,14 \\
$\quad$ X & 17 & 33,33 \\
$\quad$ XI & 12 & 23,53 \\
$\quad$ XII & & \\
Pendidikan Orang tua & 9 & 17,65 \\
$\quad$ Rendah (SD,SMP) & 36 & 70,59 \\
$\quad$ Menengah (SMA, SMK, MAN) & 6 & 11,76 \\
Tinggi (D1, D2, D3, S1) & & \\
Pekerjaan Orang Tua & 12 & 23,53 \\
$\quad$ PNS/BUMN & 39 & 76,47 \\
Non PNS & \multicolumn{2}{c}{}
\end{tabular}

Mayoritas peserta pelatihan belum pernah mendengar informasi tentang pemeriksaan payudara sendiri (SADARI) sebesar $80,38 \%$, dengan usia terbanyak berada pada rentang remaja akhir (16-19 tahun) dengan persentase sebesar 78,41\%, Status pendidikan orang tua peserta pelatihan paling banyak adalah Sekolah
Menengah Atas (SMA sederajat) yaitu sebesar 36 orang $(70,59 \%)$ dan sebagian besar pekerjaan orang tua peserta pelatihan adalah bekerja Non PNS $(76,47 \%)$ diantaranya berprofesi sebagai satpam, karyawan suasta, buruh harian dan pedagang. 


\section{Pengetahuan siswa sebelum dan setelah mengikuti pelatihan}

\section{A. Hasil Analisis Univariat}

Sebagai proses evaluasi kegiatan, maka dilakukan dengan mengukur tingkat pengetahuan peserta sebelum dan sesudah dilakukan pelatihan. Hasil analisis

univariat tingkat pengetahuan peserta pelatihan pemeriksaan payudara sendiri (SADARI) dapat dilihat pada table 2 berikut :

Tabel 2. Distribusi Frekuensi Pengetahuan Siswa Sebelum dan Setelah diberikan Penyuluhan dengan SADARI

\begin{tabular}{lrrrr}
\hline \multirow{2}{*}{ Variabel } & \multicolumn{2}{c}{ Sebelum } & \multicolumn{2}{c}{ Setelah } \\
\cline { 2 - 5 } \multicolumn{1}{c}{ Tingkat Pengetahuan } & & & $\mathrm{n}=51$ & $\%$ \\
Baik & 31 & 61 & 46 & 90 \\
Kurang & 20 & 39 & 5 & 10 \\
\hline & 51 & 100 & 51 & 100
\end{tabular}

Berdasarkan table 2. dapat disimpulkan sebagian besar peserta memiliki pengetahuan yang baik setelah mengikuti pelatihan yaitu sebesar 46 orang

\section{B. Hasil Anilisis Bivariat}

Analisis bivariat dilakukan untuk melihat ada tidaknya perbedaan signifikan tingkat pengetahuan siswi sebelum dan sesudah diberikan pelatihan. Adapun
(90\%) dan sebagian kecil yaitu sebanyak 5 orang (10\%) memiliki pengetahuan yang kurang.

perbedaan tingkat pengetahuan peserta sebelum dan setelah diberikan pelatihan dapat dilihat pada table 3 berikut:

Tabel 3. Pengetahuan Siswa Sebelum dan sesudah mengikuti pelatihan pemeriksaan

\begin{tabular}{lcccc}
\hline Tingkat Pengetahuan & Mean & $\begin{array}{c}\text { Std. } \\
\text { Deviasi }\end{array}$ & Z & $\begin{array}{c}\text { Asymp. Sig. } \\
\text { (2-tailed) }\end{array}$ \\
\hline Sebelum Pelatihan & 10.82 & 1.571 & $-5.718^{\mathrm{a}}$ & 0,000 \\
Setelah Pelatihan & 13.37 & 2.191 & & \\
\hline
\end{tabular}

Berdasarkan tabel 3. dapat dilihat hasil uji Wilcoxon Signed Ranks Test diperoleh nilai p sebesar $0.000(<\alpha=0,05)$, sehingga dapat disimpulkan tingkat pengetahuan peserta pelatihan mengalami peningkatan signifikan setelah diberi pelatihan pemeriksaan payudara sendiri (SADARI) dengan tingkat keberhasilan sebesar 23,56 \%. Prosentase keberhasilan tersebut diperoleh dengan mencari selisih mean pre tes dan post tes dibagi dengan nilai mean pre tes lalu dikalikan 100 persen.

Hasil analisis ini sejalan dengan studi yang dilakukan Karayurt, et al. (2009) dimana terdapat perbedaan yang signifikan 
secara statistik pada siswa setelah diberikan pendidikan kesehatan dibandingkan dengan sebelum pendidikan. Temuan serupa juga diperoleh Moodi et al., (2011) yang menemukan bahwa setelah 1 minggu pendidikan, skor rata-rata pengetahuan meningkat. Dalam literature terbukti bahwa penyuluhan kesehatan sangat efektif dalam meningkatkan pengetahuan tentang kanker payudara dan frekuensi melakukan SADARI. Namun sebuah studi yang dilakukan oleh Gursoy et al., (2009) dan Karayurt et al. (2009) menyelidiki efek dari peer dan kelompok pendidikan pada pengetahuan dan perilaku
SADARI juga dipengaruhi secara positif oleh pendidikan kelompok dan teman sebaya. Artinya ketika informasi kesehatan disampaikan kepada kelompok sebaya akan lebih berpengaruh dalam meningkatkan pengetahuan dan perilaku daripada disampaikan secara individu. Hal tersebut menegaskan teori yang menyatakan bahwa usia remaja sangat dipengaruhi oleh teman sebayanya. Sehingga pelatihan yang dilaksanakan pada kelompok usia yang sama dan dengan teman sebaya akan lebih efektif merubah pengetahuan dan perilaku kearah yang lebih positif.

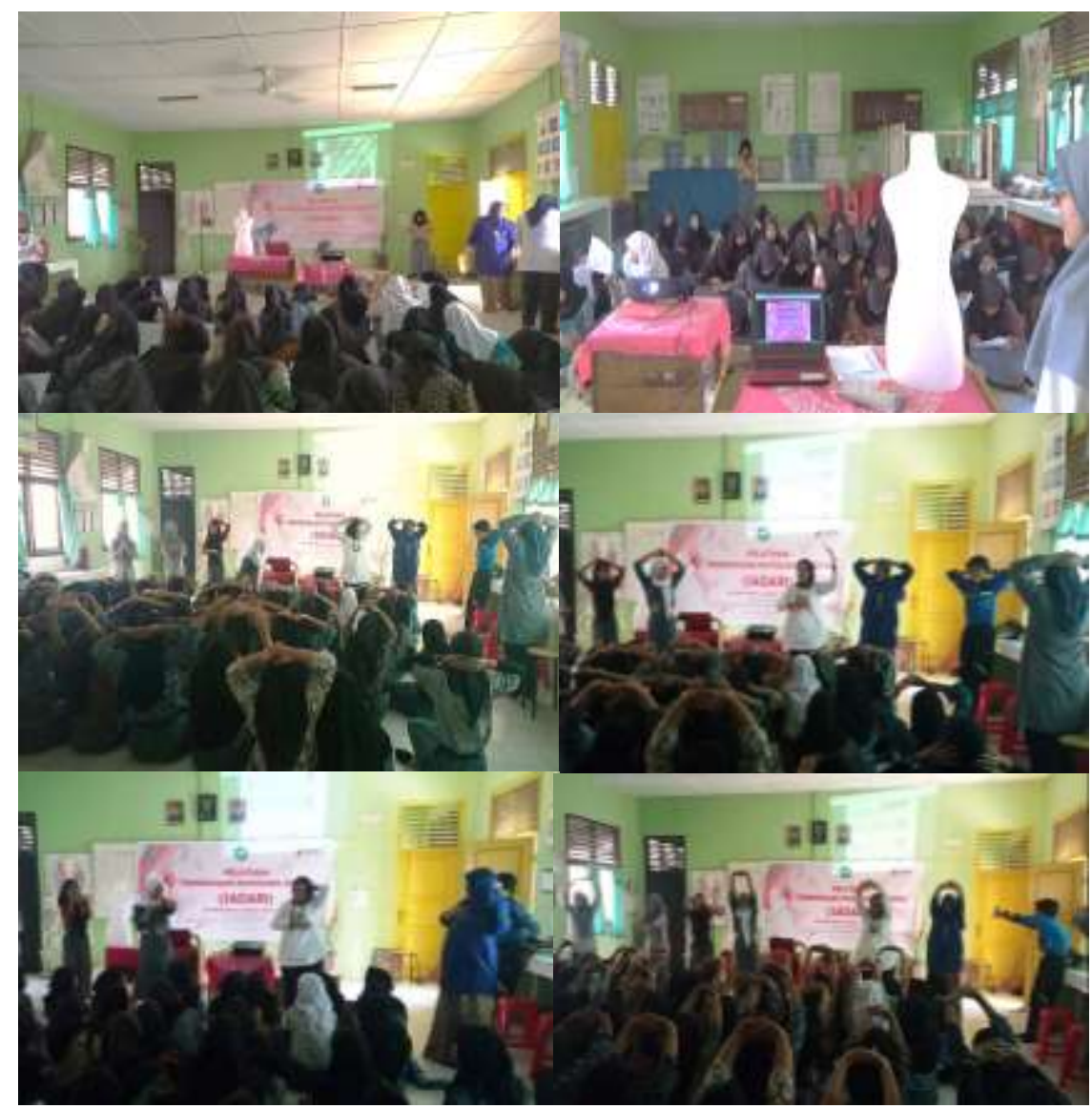

Gambar 1. Demonstrasi Pemeriksaan Payudara Sendiri (SADARI)

Hasil kegiatan pengabdian kepada masyarakat ini diharapkan remaja putri terdorong untuk melakukan SADARI secara berkesinambungan meskipun belum ada bukti bahwa SADARI mengurangi kematian akibat kanker payudara, namun setidaknya mampu mendeteksi secara dini tanda dan gejala 
kanker payudara (Akyolcu, N., Ugraş, GA., dan Akhtari-Zavare, M., et.al. 2011). Dengan mempraktikkan SADARI, remaja putri telah bertanggung jawab atas dirinya sendiri, menjadi akrab dengan payudaranya sehingga dapat melihat dan merasakan perubahan seiring waktu dan bertambahnya usia sehingga dapat segera

\section{KESIMPULAN}

Kegiatan pengabdian masyarakat yang dilaksanakan pada Siswi SMA Bina Lestari Kecamatan Gandus telah memberikan dampak positif bagi peserta pelatihan dimana sebagian besar siswi mengalami peningkatan pengetahuan yang signifikan setelah mengikuti pelatihan pemeriksaan payudara sendiri (SADARI) sebagai upaya pencegahan kanker payudara. Agar pengetahuan dan

\section{DAFTAR PUSTAKA}

Apriliana, Y. (2020). Fakultas Pertanian UGM,

https://news.detik.com/kolom/d-

5047985/new-normal-dalamperspektif-mahasiswa (diakses 17 Juli 2020)

BKKBN. 2011. Kajian Profil Penduduk Remaja 10 -24 Tahun : Ada apa dengan Remaja?. Policy Brief Puslitbang Kependudukan-BKKBN. Seri No.6/Pusdu-BKKBN/Desember 2011.

BPS (2019). Statistik Indonesia 2019. Jakarta. Diunduh pada 23 Juli 2020. Diakses dari https://www.bps.go.id/publication/20 19/07/04/daac1ba18cae1e90706ee58 a/statistik-indonesia-2019.html melaporkan setiap perubahan abnormal yang terjadi pada payudara. (Akyolcu, N., Ugraş, GA., dan Akhtari-Zavare M., et.al. 2011) dan dengan mempraktikkan SADARI remaja putri telah berpartisipasi dalam upaya promosi kesehatan dan menjadi agen perubahan untuk kelompok sebayanya.

keterampilan siswi dalam melakukan pemeriksaan payudara sendiri (SADARI) dapat permanen, maka perlu dilaksanakan pelatihan secara terjadwal serta membuat komitmen dengan pihak sekolah dan siswi yang telah mendapatkan pelatihan agar bersedia menjadi duta SADARI untuk sekolahnya dan mengajarkan kepada sebayanya.

Davies, N. G., Klepac P., Liu Y., Prem, K., Jit, M. (2020) Age-dependent effects in the transmission and control of COVID-19 epidemics. Nature Medicine volume 26, pages1205-

1211 diakses dari https://www.nature.com/articles/s415 91-020-0962-9

De Buck, E., Van Remoortel, H., Dieltjens, T., Verstraeten, H., Clarysse, M., Moens, O., \& Vandekerckhove, P. (2015). Evidence-based educational pathway for the integration of first aid training in school curricula. Resuscitation, 94, 8-22. https://doi.org/10.1016/j.resuscitation .2015 .06 .008

The Generation Guide. (2015). Millennials, Gen X, Y, Z and Baby Boomers. Diakses dari 
http://fourhooks.com/marketing/theg eneration-guide-millennials-gen- $x-y-$ z-and-baby-boomers-art5910718593/

Lee, J (2020). Mental health effects of school closures during COVID-19. Lancet Child Adolesc Health. 2020 Jun; 4(6):421. Published online 2020 Apr 14. doi: 10.1016/S23524642(20)30109-7

Kemenkes.go.id, 2020. Pencegahan Covid19 di Tempat Kerja Era New Normal, Jakarta, (diakses 17 Juli 2020)

https://www.kemkes.go.id/article/vie w/20052400003/pencegahan-covid19-di-tempat-kerja-era-newnormal.html

Kemenkes RI. 2020. COVID-19. Infeksi Emerging [serial online]. diakses 5 Juni 2020.. Diunduh dari: https://infeksiemerging.kemkes.go.id.

Kissler S, Tedijanto C, Lipsitch M, dkk. Social distancing strategies for curbing the COVID-19 epidemic. Harvard University's DASH Repository [serial online]. Maret 2020 [diakses 7 Juni 2020].

Maulana, Heri, D.J (2009). Promosi Kesehatan Jakarta : Penerbit Buku Kedokteran EGC

Moodi MM, Baladi M, Sharifirad GR, et al. Evaluation of breast selfexamination program using Health Belief Model in female students. J Isfahan Univ Med Sci. 2011;16:316. [PMC free article] [PubMed] [Google Scholar]
Nancy, Y. (2020). Tips dari Psikolog dalam Menghadapi New Normal saat Pandemi Corona. https://tirto.id/tipsdari-psikolog-dalam-menghadapinew-normal-saat-pandemi-corona$\underline{\text { fF41 (diakses } 17 \text { Juli 2020) }}$

Notoatmodjo, Soekidjo (2003). Ilmu-Ilmu Kesehatan Masyarakat (PrinsipPrinsip Dasar) cetakan ke 2 .Jakarta : Rineka Cipta,

Notoatmodjo, Soekidjo, (2007). Promosi Kesehatan dan Ilmu Perilaku Jakarta : Rineka Cipta

Anggreni, S., (2020). Pemerintah tengah mempersiapkan Indonesia memasuki era new normal, namun siapkah remaja menghadapinya? https://www.kisara.or.id/artikel/kesia pan-remaja-menuju-era-newnormal.html (diakses 17 Juli 2020)

Susilo A, Rumende CM, Pitoyo CW, dkk.(2020) Coronavirus Disease 2019: Tinjauan Literatur Terkini. $J$ Penyakit Dalam Indonesia.7:45-77. http://jurnalpenyakitdalam.ui.ac.id/in dex.php/jpdi/article/view/415/228

Surat Keputusan Menteri Kesehatan nomor HK.01.07/MENKES/328/2020 tentang Panduan Pencegahan dan Pengendalian Corona Virus Disease 2019 di Tempat Kerja Perkantoran dan Industri dalam Mendukung Keberlangsungan Usaha pada Situasi Pandemi. 
WHO (2020). WHO Director-General's opening remarks at the media briefing on COVID-19 . World Health Organization [serial online]. Diunduh dari: https://www.who.int/dg/speeches/det ail/w ho-director-general-s-openingremarks at-the-media-briefing-oncovid-19---11- march-2020 